Dr. Otto Glaser (Amherst) who introduced the conferenco to a new method of formulating the growth of organisms and their chemical constituents.

'Tho last full day opened with a highly stimulating paper from Dr. Schottó (Amherst) on regeneration. After briefly reviewing the old question of the origin of the material of tho regeneration blastema in invertebrates and vertebrates, ho went on to deal with the vexed but important problem of the 'toti. potency' of the regeneration blastema in Amphibia. Admitting that limb-competence in the tail-blastema or vico versa has not as yet been definitely proved, ho xent on to describo his remarkablo experiments which indicato that lens-competenco, though long absent from the body epidermis, reappears in the material of tho tail blastema. It seems also to reappear in regenerating epidermis over tho oye. Notochord implanted in tail blastema has also induced pronephric and neural tissuo. Should theso findings be further confirmed and generally received, a now word will bo needed to describo tho return of competence after its ontogenetic disappearance. From the floor of the houso the word 'recuperation' was suggested, and this seemed to find somo favour. In any ovent, as Ross Harrison has pointed out, there are undeniable instances of reversals of deter. mination, as in tunicates, so the return of competence in vertebrates would not be quito unoxpected. Tho afternoon session on this day was devoted to the studies of Dr. Sinnott (New York) on gene-controlled shape in cucurbitaceous fruits; this led to a vigorous discussion of field-concepts, which had been brewing during former sessions.

On the last morning Dr. Woodger (London) explained tho advantages which would accruo to biologists in framing their theories if use was made of logistic technique, of which he gave some examples. Ho also directed attention to certain points of interest for biological theory which had arisen during tho mectings.

On the whole, the meotings were remarkable for the degreo of unanimity of thought on funda. mental problems which provailed, as perhaps must bo the case when there is enough time to explain individual points of view in a spirit of moderation and candid sincerity. Apart from those who con. tributed lectures, the discussions were greatly enlivened by the presence of such workers as Dr. Berrill (Aontreal), Dr. Hoadloy (Harvard), Dr. 'Thimann (Harvard), Dr. Paul Weiss (Chicago), Dr. Frank Daniel (Berkeley), Dr. Barth (New York), Dr. Reimann and Dr. Hammett (Philadelphia) who showed a film illustrating differentiation and dedifferentiation in Obelia, Dr. L. C. Dunn (New York), Dr. Samuel Brody (Missouri), Dr. Hamburger (St. Louis) and Dr. Frank (New York). At the end of the conferenco suitable steps wero taken to form an organization able to call together similar conferences on growth and differentiation in futuro years.

\title{
TABOO*
}

$\mathrm{T}$ HE use of the word 'taboo' in anthropology for customs all over the world, which resemble in essentials the reference adopted from Polynesia, seems undesirable and inconvenient. For such customs the terms 'ritual avoidance' or 'ritual prohibition' aro proposed, defining them by reference to two fundamental concepts, 'ritual status' and 'ritual value'. A ritual prohibition is a rulo of behaviour which is associated with \& belief that an infraction will result in an undesirable chango in the ritual status of the person who fails to keep the rulo; that is, it involves the likelihood of some minor or major misfortune which will befall the person concorned.

Anything which is tho object of a ritual avoidance or taboo may be said to have ritual value. 'The ritual value is exhibited in the behaviour adopted towards the object or occasion in question-not only in the negativo ritual, but also in the positive ritual. A large class of positive rites, those of consecration or sacralization, have for their purpose to endow objects with ritual value.

Tho word 'value' as thus used always refers to a relation between a subject and an object. It may refer to the act of behaviour towards an object. A social system can bo conceived and studied as a system of values. A society cannot oxist except on a basis of a certain measure of similarity in the interests of its members. In terms of values the first necessary condition of the existenco of a society is that the individual members should agreo in some

- From the Frazcr Lecture, 1939, bs Prof. A. R. Radeliffe-Bronn. Cambridge: At the University Press, 1939. Pp. 49. 2s. Od. net.) measure on the values that they recognize. To avoid misunderstanding it is necessary to add that a social system also requires that persons should bo objects of interest to others.

The study of ritual may bo approached by the consideration of the purpose or reasons for the rite, or by a consideration of its meaning. A third method is by consideration of the effects - the direct effect on the person concerned, which may be termed the psychological effect, and the secondary effect on the social structure, the network of social relations binding individuals together in an ordered lifo-the social effect. By consideration of theso wo may succeed in defining the psychological function, and in discovering the social function of a rite.

The rites are readily perceived to be symbolic. The immediato psychological effect can to some extent bo observed by watching and talking to the performers. The ostensible purposo is present in their minds, but so also is that complox set of cosmological beliefs by reference to which the rito has a meaning. In the performance of the rite the native has mado a con. tribution to the maintenance of the order of the universe, of which man and Nature are the interdependent parts.

Assuming that the act is symbolic, what method, other than that of guessing, is there of arriving at its meaning ? Wo may start with a general working hypothesis that when in a single society the same symbol is used in different contexts, or on different kinds of occasions, thero is a common element or meaning, and that by comparing the various uses of the symbol we may be able to discover what the 
common element is. Thus taking certain customs of avoidance in the Andaman Islands, it would appear that the common element is that the individual affected is in an abnormal ritual status and is likely. to suffer some misfortune unless certain prescribed ritual precautions are observed, such as the avoidance of certain foods, while friends or others avoid the use of the individual's personal name. By means of theso taboos the occasion acquires a certain social value. But while these rites give men confidence, comfort, and a sense of security, they might equally cause fear, that is, from black magic or spirits. It is largely by the sharing of hopes and fears that human beings are linked together in temporary or permanent associations.

The symbolic rites of the Andamanese are the obligatory recognition of a standardized symbolic form of the significance and importance of the event to individuals and the community at large. They serve to fix the social value of occasions of this kind. So with the food taboos, they attach a definite social value to food, and it is in the activities connected with the getting and consuming of food, with their daily. instances of collaboration and mutual aid, that there continually occur those inter-relations of interests which bind the individual men, women, and children into a society. This may bo generalized under the formulation that the primary basis of all ritual, and therefore of all religion and magic, is the attribution of ritual value to objects and occasions which are either themselves objects of important common interests linking together the persons of a community or are symbolically representative of such objects.

\section{ECONOMIC BOTANY IN THE TROPICS}

GIR FRANK STOCKDALE, in his interesting address, on "The Application of Economic Botany in the Tropics", which had been prepared for the Dundee meeting of the British Association but was not delivered owing to the cancellation of the meeting, points out that many of the economic erop plants now commonly grown in the tropics were distributed when now lands were discovered in Elizabethan times. Tobacco, for example, from tropical America; sugar cane and the banana from the Old World; cacao from Central and South America, and rubber from Brazil. Coffeo is indigenous in tropical Africa, and China and Cochin China appear to be the original home of the citrus group.

Following early haphazard distribution came the introduction of Cinchona to India by Markham and Ledger and of rubber to Ceylon by Wickham, both through the auspices of the Royal Botanic Gardens, Kew.

The introduction of coffee to Coylon and the outbreak of coffee-leaf disease there resulted in arousing scientific interest in tropical crops. Had Marshall. Ward, who went out to investigate the disease, had available the important research work on the rooting systems and the effect of light on the stomatal mechanism in Coffea arabica, which Nutman has recently done at Amani, it is possible the Ceylon coffee industry might have been saved.

The West Indian sugar cane industry was similarly faced with disaster through disease, but, thanks to the work of Harrison and Bovell in raising seedlings from different varieties of Saccharum officinarum, new types-'noble canes'-were introduced and disease-resistant strains raised. This work, continued by Barber at Coimbatore, India, has been carried on successfully there under Venkataraman and by the Dutch workers in the Netherlands East Indies. $S$. spontaneum has been used in crossing, as well as other allied species, and valuable canes have resulted, notably the well-known P.O.J. 2878 which came from a third 'mobilization' of $S$. spontaneum. Types of cane suitable for different types of soil have also resulted from these cross-breeding researches.

Sir Frank then deals with the cotton crop and the valuable work which has been done in Egypt, the Sudan, India and the United States, etc., which have resulted in marked improvements in yield, lint length and fineness, and strength of lint, while diseaso resistance has also received much attention with valuable results.

Both Cinchona and rubber have been subjected to careful scientific investigation which has led to the recognition of high- and poor-yielding strains, and the selection of high-yielding 'mother-trees' for budding. Hybridizing work on rubber is now being carried out and a search is being mado also for strains resistant to the Oidium mildew which is causing serious damage to rubber in the East.

The work now in progress in Trinidad with cacao is fully dealt with and the important discovery of incompatibility in cacao is referred to. Unfortunately it has now been found that some of the best yielding strains are self-incompatible, which upsets some of the earlier work, though the discovery has enabled the work to be prosecuted on fresh lines.

Sir Frank finally deals with the work that is in progress in the improvement of rice and other crop plants and with the work at Amani on raising strains of Cassava immune to mosaic disease.

$\mathrm{He}$ concludes with the following very apposite remarks :

"The breeding of resistant forms is the most effective method by which to overcome the diffculties facing producers, and co-operative work by plant breeders and pathologists is required if a satisfactory solution of the present-day problems is to be found.

"Improved types of crop plants, however, demand higher standards of agriculture and whilst it is to be expected that improvements may be achieved from further collections of wild forms for special breeding work and from the interchange of strains which have already been evolved, sound developments are likely only to be secured by a general advance in methods of husbandry designed to ensure soil conservation and the maintenance of its fertility, and by the adoption of those agricultural systems which are suited to the particular environment. In this field much work still remains to be done and additional teams of research workers with specialized training are required in the approach to the problems which are presented to those who are responsible for the welfare of the Colonial Empire." 